\title{
GINGIVAL ULCERATIONS IN A PATIENT WITH ACUTE MYELOID LEUKEMIA: A CASE REPORT AND LITERATURE REVIEW
}

\author{
Vanja Vučićević Boras ${ }^{1,2}$, Danica Vidović Juras ${ }^{1,2}$, Igor Aurer ${ }^{3}$, \\ Sandra Bašić-Kinda ${ }^{3}$ and Mirta Mikulić ${ }^{4}$
}

\author{
${ }^{1}$ Department of Oral Medicine, School of Dental Medicine, University of Zagreb; \\ ${ }^{2}$ Department of Oral Diseases, Zagreb University Hospital Centre, Zagreb, Croatia; \\ ${ }^{3}$ Department of Hematology, School of Medicine and Zagreb University Hospital Centre, Zagreb, Croatia; \\ ${ }^{4}$ Croatian Bone Marrow Donor Registry, Zagreb University Hospital Centre, Zagreb, Croatia
}

SUMMARY - A 40-year-old female patient was admitted to the Department of Oral Medicine due to oral ulcerations. Oral ulcerations were present on vestibular mucosa above teeth 21, 22, 25 and 26 and were $1 \mathrm{~cm}$ in diameter, and also around teeth 45 and 46 . The patient had prolonged neutropenia due to therapy-related myelodysplastic syndrome that progressed to therapy-related acute myeloid leukemia. Initially, the patient was successfully treated with polychemotherapy for non-Hodgkin lymphoma. Unfortunately, many toxic complications ensued, such as peripheral neuropathy, dilated cardiomyopathy and therapy-related myelodysplastic syndrome/therapy-related acute myeloid leukemia. The onset of therapy-related myelodysplastic syndrome was less than six months after initiation of chemotherapy treatment, which was rather early, but cytogenetic changes (monosomy 5 and 7) were consistent with the diagnosis. Upon admission to our Department, microbiological swabs were obtained and were all negative, while $\mathrm{x}$-ray finding showed that ulcerations did not have dental cause. Biopsy was not obtained as the patient had severe neutropenia and thrombocytopenia. While viral and fungal swabs were negative, Stenotrophomonas maltophilia was cultured from the oral cavity. Thus, differential diagnoses are listed in this report. Neutropenic ulcerations did not heal albeit extensive medicamentous oral and systemic treatments were applied and the patient died.

Key words: Leukemia, myeloid, acute; Gingivitis, necrotizing, ulcerative; Case reports

\section{Introduction}

Oral neutropenic ulcerations have been so far described in patients suffering from neutropenia, multiple myeloma, and acute as well as T-large cell leukemia $^{1-4}$. Barrett and Buckley ${ }^{2}$ report that neutropenic ulceration and herpes simplex infection were the major causes of morbidity in three patients following administration of high-dose melphalan for the treatment of

Correspondence to: Danica Vidović Juras, School of Dental Medicine, University of Zagreb, Gundulićeva 5, HR-10000 Zagreb, Croatia

E-mail: dvjuras@gmail.com

Received July 8, 2014, accepted December 15, 2015 multiple myeloma. In 2000, Copete and Sheridan ${ }^{3}$ concluded that it was still unclear whether ulcerations in the oral cavity of patients undergoing leukemia treatment were caused by infective etiology or they were manifestations of neutropenia. The same was concluded by Arvanitidou et al. ${ }^{4}$ in 2011. It seems that the degree of susceptibility to infection is roughly proportional to the blood neutrophil count.

However, it seems that oral ulcerations in leukemic patients might be a result of the following: 1) oral ulcerations might be induced by neutropenia in leukemic patients; 2) oral ulcerations may be a side effect of cytotoxic chemotherapy or develop as a consequence of direct toxicity of the medication itself. It is well 
known that chemotherapy agents such as methotrexate might induce oral ulcerations and that these might be dose dependent. It is well recognized that patients may benefit from temporary discontinuation of methotrexate ${ }^{4}$; and 3) infectious etiology of oral ulcerations.

In the literature published so far, there have been few case reports on bacterial species such as oral $F u^{-}$ sarium moniliforme $e^{5}$, Capnocytophaga ochracea and sputigena $^{6,7}$, Leptotrichia trevisanii ${ }^{8}$, and Streptococcus mitis ${ }^{9}$ infection which manifested as necrotic gingival ulceration in granulocytopenic patients. Furthermore, there also are case reports on viral infection such as herpes simplex virus ${ }^{10-11}$, Epstein-Barr virus ${ }^{12}$, cytomegalovirus $^{13}$ in the oral cavity in patients undergoing chemotherapy for hematologic malignancies. The last but not the least, fungal infections such as candidiasis ${ }^{14}$, aspergillosis ${ }^{15}$, mucormycosis ${ }^{16}$ and histoplasmosis ${ }^{17}$ might be encountered in these patients.

Barrett et al. ${ }^{18}$ report that oral complications were detected in $89 \%$ of hospital admissions for treatment of acute leukemia in adults. Changes that reflected the underlying myelosuppression and general immunosuppression predominated. Hemorrhagic phenomena (77\%), neutropenic ulceration (49\%), and herpes simplex virus infections (39\%) were the most common ones. Beattie et al. ${ }^{19}$ report that mouth ulcers are a frequent cause of morbidity in patients rendered neutropenic as a result of chemotherapy. The same authors ${ }^{19}$ report that herpes simplex virus (type I) was isolated in 13 patients and Candida albicans cultured in 17 patients. Both organisms were isolated in 9 patients. Their results suggest that both viral and fungal elements may be important in the etiology of oral ulceration and that antiviral and antifungal agents may each have a role in the prophylaxis and treatment of such patients.

\section{Case Report}

A 40-year-old female patient was referred to the Department of Oral Medicine due to painful oral lesions. Clinical examination revealed oral ulceration on the vestibular mucosa above teeth $21,22,25$ and 26 , which were $1 \mathrm{~cm}$ in diameter. There was also oral ulceration $3 \mathrm{~mm}$ in diameter behind tooth 46 in the retromolar area and on the tongue. Tooth 46 was implant supported crown. All ulcerations were covered with thick pseudomembranes and minimal surrounding inflammation. According to the orthopantomogram and

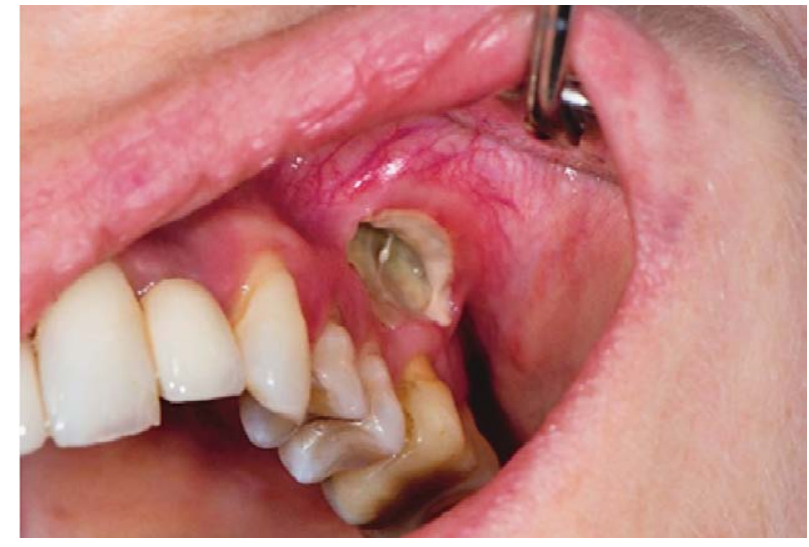

Fig. 1. Neutropenic ulceration on the gingiva above teeth 24,25 and 26.

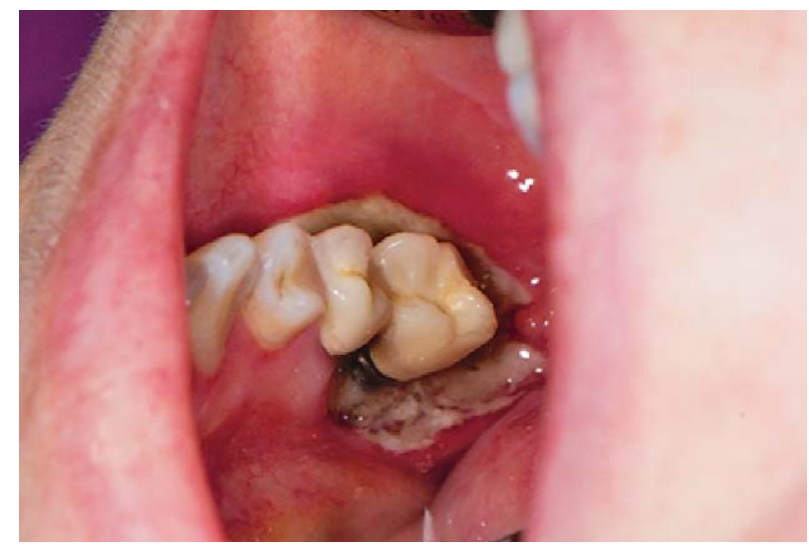

Fig. 2. Neutropenic ulceration on the gingiva around teeth 45 and 46.

vitality tests of the teeth, we concluded that ulcerations were of non-odontogenic origin. No plaque deposits on the teeth could be noticed.

Ten months before her referral to the specialist in oral medicine, the patient was diagnosed with diffuse large B-cell lymphoma, stage IVA. She received five cycles of chemotherapy according to the R-CHOEP protocol (rituximab, cyclophosphamide, doxorubicin, vincristine, methylprednisolone and etoposide), followed by three cycles of R-CHEVP (rituximab, cyclophosphamide, doxorubicin, etoposide, vinblastin and methylprednisolone) due to toxic neuropathy. Complete remission of lymphoma was achieved, but the clinical course was further complicated by the development of dilated cardiomyopathy two months after completion of hematologic treatment. In addition, prolonged thrombocytopenia was observed during the last two cycles of R-CHEVP and five months after 
initiating the treatment, bone marrow aspirate was examined due to pancytopenia. While the myleogram showed no abnormalities, $10 \%$ myeloblasts were found by immunophenotyping and monosomy of chromosomes 5 and 7 by cytogenetics. On repeated bone marrow examination two weeks later, myelogram showed $13 \%$ myeloblasts and the finding was classified as refractory anemia with excess blasts-2 (RAEB-2). Since RAEB developed after chemotherapy treatment, it was considered to be treatment-related. The patient received supportive therapy, mainly platelet transfusions and antimicrobial prophylaxis, and also a short course of thioguanine which led to severe neutropenia. Seven months after starting chemotherapy treatment, the bone marrow finding progressed to acute myeloid leukemia with $40 \%$ blasts. Due to severe cardiomyopathy, the patient was unsuitable for intensive chemotherapy and was treated with three cycles of azacitidine during which time she also received antimicrobial prophylaxis with ciprofloxacin, acyclovir and fluconazole. After completion of the first cycle of azacitidine, the patient developed oral ulcerations for which she was referred to the Department of Oral Medicine.

Upon referral to the Department of Oral Medicine, her blood tests showed pancytopenia with leukocytes $0.9\left(\mathrm{x} 10^{9}\right)$ (normal range 3.4-9.7), red blood cells $3.38\left(\mathrm{x} 10^{12}\right)(4.34-5.72)$, hemoglobin $99(\mathrm{~g} / \mathrm{L})(138-$ $175)$, mean corpuscular volume 88 (fL) (83-97.2), and platelets $29\left(\mathrm{x} 10^{9} / \mathrm{L}\right)(158-424)$. The patient was taking Lanitop (methyldigoxin), Fursemid (furosemide), Tritace (ramipril), Aldactone (spironolactone), Carvelol (cervedilol), Controloc (pantoprazole), Diflucan (fluconazole), Ciprofloxacin (ciprofloxacin).

In order to alleviate pain and oral ulcerations, she was advised to take mouthwash three times a day $(\mathrm{Cu}-$ rasept, Curaprox, 0.05\%), Dolokain gel (lidocaine), Gelclair (Helsinn Healthcare SA, Lugano, Switzerland), Diflamm solution (benzydamine hydrochloride, $3 \mathrm{M}$ ), and betamethasone (Beloderm, Belupo, Koprivnica, Croatia) in orabase.

Unfortunately, throughout azacitidine treatment, the patient had severe neutropenia and eventually died from infectious complications, i.e. Staphylococcus hominis sepsis and Aspergillus flavus rhinosinusitis.

\section{Discussion}

In our patient, oral fungal and viral swabs were all negative upon admission, therefore we concluded that ulcerations were exclusively due to neutropenia. Biopsy specimen was not obtained as the patient was severely thrombocytopenic and received blood transfusion almost every other day.

Several days before the patient died, oral microbial tests had shown the presence of Stenotrophomonas maltophilia and Enterobacterium foecalis. Stenotrophomonas maltophilia is an anaerobic gram-negative bacillus found in aquatic environments. It is an opportunistic microorganism of low virulence. Stenotrophomonas maltophilia causes infection in immunosuppressed hosts, especially those with neutropenia, on chemotherapy and broad-spectrum antibiotics ${ }^{20}$. To our knowledge, there are only two case reports on exclusive Stenotrophomonas maltophilia infection in the oral cavity. Miyairi et al. ${ }^{21}$ described an immunocompromised patient with acute ulcerative necrotic gingivitis and bacteremia due to Stenotrophomonas maltophilia. Soga et al..$^{22}$ described a patient with appearance of multidrug-resistant Stenotrophomonas maltophilia on the gingiva during leukemia treatment.

Based on our case, it seems that detection of Stenotrophomonas maltophilia and Enterobacterium foecalis was a concomitant finding in the oral cavity as neutropenic ulcers had been present for three months before these bacteria were found. However, we do agree with Teo et al. ${ }^{20}$ that the finding of mucocutaneous infections in neutropenic patients with malignancies seem to be a poor prognostic sign.

Differential diagnoses of ulcerations in neutropenic patients might be acute necrotizing ulcerative gingivitis, leukemic infiltrates, ulcers induced as a direct consequence of chemotherapy, bacterial, viral or fungal infection ${ }^{23}$.

In patients undergoing leukemia treatment, gingiva acts as a site of proliferation and reservoir of multidrug-resistant opportunistic bacteria. To prevent abnormal increases in such bacteria on the gingiva, scaling and/or root planing together with local antiseptic and local/systemic antibiotic may contribute to infection control in such patients. This is sometimes impossible as patients may have severe neutropenia or thrombocytopenia, as seen in our case, as well as in cases reported by Arvanitidou et al. ${ }^{4}$.

In most cases, neutropenic ulcerations will clear up as the neutrophil count returns to normal values. However, it was not the case in our patient as the patient died. 


\section{Conclusion}

Prolonged neutropenia, as in this case of a patient with therapy-related myelodysplastic syndrome/therapy-related acute myeloid leukemia, was the underlying cause of oral ulcers rather than chemotherapy. In our patient, the presence of Stenotrophomonas maltophilia was considered as colonization. The last but not the least, all oral therapeutic procedures failed to improve oral ulcerations in our patient.

\section{References}

1. Hastürk H, Tezcan I, Yel L, Ersoy F, Sanal Ö, Yamalik N, et al. A case of chronic severe neutropenia: oral findings and consequences of short-term granulocyte colony-stimulating factor treatment. Aust Dent J. 1998;43:9-13, https://doi.org/10.1111 /j.1834-7819.1998.tb00144.x

2. Barrett AP, Buckley DJ. Oral complications of high-dose melphalan in multiple myloma. Oral Surg Oral Med Oral Pathol. 1987;64:264-7, https://doi.org/10.1016/0030-4220(87)90102-2

3. Copete MA, Sheridan DP. Large granular lymphocyte leukemia and its association with oral neutropenic ulceration. Oral Surg Oral Med Oral Pathol Oral Radiol Endod. 2000;90: 474-7, https://doi.org/10.1067/moe.2000.107972

4. Arvanitidou IE, Nikitakis NG, Sklavounou A. Oral manifestations of T-cell large granular lymphocytic leukemia: a case report.J Oral Maxillofac Res.2011;2:e4,https://doi.org/10.5037/ jomr.2011.2304

5. Myoken Y, Sugata T, Kyo T, Fujihara M. Oral Fusarium infection in a granulocytopenic patient with acute myelogenous leukemia: a case report. J Oral Pathol Med. 1995;24:237-40, https://doi.org/10.1111/j.1600-0714.1995.tb01174.x

6. Kristensen B, Schønheyder HC, Peterslund NA, Rosthøj S, Clausen N, Frederiksen W. Capnocytophaga (Capnocytophaga ochracea group) bacteremia in hematological patients with profound granulocytopenia. Scand J Infect Dis. 1995;27:153-5, https://doi.org/10.3109/00365549509018997

7. Funada H, Machi T, Yoneyama H, Matsuda T, Miura H, Ezaki T, Yokota Y. Capnocytophaga sputigena bacteremia associated with acute leukemia. Kansenshogaku Zasshi. 1993;67:622-8, https://doi.org/10.11150/kansenshogakuzasshi1970.67.622

8. Kumagai J, Takiguchi Y, Shono K, Suruga Y, Akiba Y, Yamamoto K, Terano T. Acute myelogenous leukemia with Leptotrichia trevisanii bacteremia. Intern Med. 2013;52:2573-6, https://doi.org/10.2169/internalmedicine.52.9580

9. Arning M, Gehrt A, Aul C, Runde V, Hadding U, Schneider W. Septicemia due to Streptococcus mitis in neutropenic patients with acute leukemia. Blut. 1990;61:364-8, https://doi.org/ 10.1007/bf01738551

10. Shibuya T, Moriyama K, Harada M, Okamura T, Taniguchi S, Akashi K, Mori R, Niho Y. Herpes simplex virus in oral mucosal ulcers in patients with hematological malignancy. Jpn J Clin Oncol. 1989;19:348-52.
11. Janmohamed R, Morton JE, Milligan DW, Leyland MJ, Coupland B. Herpes simplex in oral ulcers in neutropenic patients. Br J Cancer. 1990 Mar;61(3):469-70, https://doi.org/10.1038/ bjc. 1990.103

12. Cho HH, Kim SH, Seo SH,Jung DS, Ko HC, Kim MB, Kwon KS. Oral hairy leukoplakia which occurred as a presenting sign of acute myeloid leukemia in a child. Ann Dermatol. 2010; 22:73-6, https://doi.org/10.5021/ad.2010.22.1.73

13. Lloid ME, Schubert MM, Myerson D, Bowden R, Meyers JD, Hackman RC. Cytomegalovirus infection of the tongue following marrow transplantation. Bone Marrow Transplant. 1994;14:99-104.

14. Sepúlveda E, Brethauer U, Rojas J, Fernández E, Le Fort P. Oral ulcers in children under chemotherapy: clinical characteristics and their relation with herpes simplex virus type 1 and Candida albicans. Med Oral Patol Oral Cir Bucal. 2005;10 1: E1-8.

15. Myoken Y, Sugata T, Kyo TI, Fujihara M. Pathological features of invasive oral aspergillosis in patients with hematologic malignancies. J Oral Maxillofac Surg. 1996 Mar;54(3):263-70, https://doi.org/10.1016/s0278-2391(96)90737-5

16. Al Akhrass F, Debiane L, Abdallah L, Best L, Mulanovich V, Rolston K, Kontoyiannis DP. Palatal mucormycosis in patients with hematologic malignancy and stem cell transplantation. Med Mycol. 2011;49:400-5, https://doi.org/10.3109/1369378 6.2010 .533391

17. Kauffman CA, Israel KS, Smith JW, White AC, Schwarz J, Brooks GF. Histoplasmosis in immunosuppressed patients. Am J Med. 1978;64:923-32, https://doi.org/10.1016/00029343(78)90445-x

18. Barrett AP. A long-term prospective clinical study of oral complications during conventional chemotherapy for acute leukemia. Oral Surg Oral Med Oral Pathol. 1987;63:313-6, https:// doi.org/10.1016/0030-4220(87)90196-4

19. Beattie G, Whelan J, Cassidy J, Milne L, Burns S, Leonard R. Herpes simplex virus, Candida albicans and mouth ulcers in neutropenic patients with non-haematological malignancy. Cancer Chemother Pharmacol. 1989;25(1):75-6, https://doi. org/10.1007/bf00694344

20. Teo WY, Chan MY, Lam CM, Chong CY. Skin manifestation of Stenotrophomonas maltophilia infection - a case report and review article. Ann Acad Med Singapore. 2006;35:897-900.

21. Miyairi I, Franklin JA, Andreansky M, Knapp KM, Hayden RT. Acute necrotizing ulcerative gingivitis and bacteremia caused by Stenotrophomonas maltophilia in an immunocompromised host. Pediatr Infect Dis J. 2005;24:181-3, https://doi. org/10.1097/01.inf.0000151038.82538.de

22. Soga Y, Saito T, Nishimura F, Ishimaru F, Mineshiba J, Mineshiba F, et al. Appearance of multidrug-resistant opportunistic bacteria on the gingiva during leukemia treatment. J Periodontol. 2008;79:181-6, https://doi.org/10.1902/jop.2008.070205

23. Porter SR, Leao JC. Oral ulcers and its relevance to systemic disorders. Aliment Pharmacol Ther. 2005;21:295-306, https:// doi.org10.1111/j.1365-2036.2005.02333.x 


\section{Sažetak \\ ULCERACIJE GINGIVE U BOLESNICE S AKUTNOM MIJELOIDNOM LEUKEMIJOM: PRIKAZ SLUČAJA I PREGLED LITERATURE}

\section{Vučićević Boras, D. Vidović Juras, I. Aurer, S. Bašić-Kinda i M. Mikulić}

Bolesnica u dobi od 40 godina primljena je na Zavod za oralnu medicinu zbog oralnih ulceracija. Oralne ulceracije promjera $1 \mathrm{~cm}$ bile su prisutne na vestibularnoj sluznici iznad zuba 21,22, 25 i 26, a također i oko zuba 45 i 46 . Bolesnica je imala produljenu neutropeniju uslijed mijelodisplastičnog sindroma povezanog s terapijom, koji je progredirao $u$ akutnu mijeloidnu leukemiju povezanu s terapijom. U početku je bolesnica uspješno liječena polikemoterapijom za non-Hodgkinov limfom. Nažalost, uslijedile su mnoge toksične komplikacije poput periferne neuropatije, proširene kardiomiopatije i mijelodisplastičnog sindroma povezanog s terapijom/akutne mijeloidne leukemije povezane s terapijom. Terapijski mijelodisplastični sindrom pojavio se u manje od šest mjeseci nakon započinjanja liječenja kemoterapijom, što je bilo prilično rano, ali su citogenetske promjene (monosomija 5 i 7) bile u skladu s dijagnozom. Nakon dolaska na naš Zavod učinjeni su mikrobiološki brisevi i svi su bili negativni, a rendgenski nalaz je isključio odontogenu etiologiju ulceracija. Biopsija nije učinjena, jer je bolesnica imala tešku neutropeniju i trombocitopeniju. Iako su virusni i gljivični brisevi bili negativni, Stenotrophomonas maltophilia izolirana je iz usne šupljine. Stoga su u ovom prikazu navedene različite dijagnoze. Unatoč ekstenzivnim oralnim i sistemskim tretmanima neutropenične ulceracije nisu zacijelile, a bolesnica je preminula.

Ključne riječi: Leukemija, mijeloidna, akutna; Gingivitis, ulcerativni; Prikazi slučaja 